\title{
MASS MEDIA COMMUNICATION \& COMPANIES' MARKET POSITION: THE CASE OF THE CZECH MORTGAGE MARKET ${ }^{1}$
}

\author{
Daria Gunina, Michal Novák, Tomáš Kincl, Lenka Komárková*
}

\begin{abstract}
The study analyses mass media communication by mortgage lenders in the Czech market and builds on Kotler's competitive strategies concept and aims to answer the question of whether there is a relationship between the mortgage lenders' market position and their mass media communication profile. Furthermore, it analyses the mass media communication of mortgage lenders according to their financial performance. The analysis utilises complete monitoring data from the mass media market in the Czech Republic. As a result of this study, the different advertising patterns of the market leaders and challengers on a highly commoditised market are shown. Market leaders do not utilise defensive strategies to protect their market shares but employ more offensive strategies to increase the size of the market. Market challengers have no resources to implement a massive and offensive communication strategy to challenge the market leaders. Such a conclusion contributes to the debate on communication strategies for distinct types of companies according to their position on the market and their market share.
\end{abstract}

Keywords: mass media communication, mortgage market, television, advertising JEL classification: M37, G21, M21

\section{Introduction}

Most people buy a property only a few times or just once in their life. The buyers usually financially stretch themselves and most opt for additional funding. The market offers a plethora of financial services, among which a mortgage or housing loans are the most widely used. From the marketing perspective, a mortgage loan as a product/service does not provide many opportunities for differentiation. The major decisive buying criterion is the interest rate, while the relationship between mortgage lenders and their customers is rather transactional (Nielsen Admosphere, 2015; Accenture, 2015). However, the variation in the interest rates offered by the lenders is almost negligible and the market is highly commoditised (Allen et al., 2014). This is also the situation on the Czech mortgage market, as the country has closed the gap on the well-established and developed western markets since the 1990s (CNB, 2015).

On such commoditised markets, the companies primarily aim to raise their market share to establish and maintain a competitive advantage (Wright and Watkins, 2010). The market leaders aim to maintain their dominance by expanding the total market size and to defend their current position against challengers' attacks, while smaller companies and new entrants attempt to move up and to obtain a share of their

1 This work was supported by internal support funding IGS F6/01/2018.

* Faculty of Management, University of Economics, Prague (daria.gunina@vse.cz; michal.novak@vse.cz; tomas.kincl@vse.cz; komarkol@fm.vse.cz). 
competitors (Kotler and Armstrong, 2012). On an undifferentiated market, this happens through intensive marketing communication. Financial institutions (banks) utilise a variety of marketing communication mix tools, among which advertising remains the most prominent instrument to promote companies or their products/services (Rosen, 1989). A widely accepted rule of thumb suggests that market leaders usually require less advertising expenditure (relative to sales) to protect their market share than their challengers (Kotler and Keller, 2016). Moreover, the returns on advertising increase with company size on the financial markets (Mullineaux, 2011). To increase their market share, smaller or newly established financial institutions should run more intensive and/ or more effective advertising campaigns than the leaders (Honka et al., 2017). However, only the industry key players can afford complex and integrated marketing campaigns, since the media market is highly saturated and advertising space is extremely expensive (Geskey, 2015). Again, this has also been experienced on the Czech media market in the last decade (Zahrádka and Sedláková, 2012).

Most authors examined the relationship between advertising and sales using data on advertising expenditures and revenues or sales. Borden (1942) suggested that advertising influences selective demand (demand for advertised product) although industry demand or aggregate demand depends mostly on other factors. Cowling et al. (1975) found a positive correlation between advertising and aggregate demand in the cigarette market, but no correlation on the coffee market. Grabowski (1977) found advertising intensity influenced market share in the soft drinks and cereals market. Kwoka (1993) claimed an advertising-sales relationship in the car market. However, Nelson (2005) found little evidence in the beer industry, similarly to Cavaliere and Tassinari (2001) in the whisky market. Advertising does not influence sales of petrol or bicycles since the demand usually depends on prices (bicycles) (Steiner, 1978) or on the number of filling stations (petrol) (Grabowski, 1977; Patterson, 1977). Therefore, the influence of advertising on aggregate demand varies in different industries. Such an assumption is also the motivation to analyse the relationship between sales and advertising in the Czech mortgage market $(\mathrm{Q} 4)$. The question also remains whether advertising influences demand or vice versa. Taylor and Weirserbs (1971) suggested that advertising can influence demand, but the variables are in the mutual relationship and the direction of influence cannot be defined.

The motivation for this research is to reveal whether the financial institutions offering mortgage or housing loans on the Czech market communicate differently regarding their age, financial strength, and market position. Thus, we formulated the following research questions:

- Q1: "Is there a difference in advertising activity between the younger mortgage lenders and the older ones on the Czech mortgage market?"

- Q2: "Is there a difference in advertising activity between the market challengers and the market leaders on the Czech mortgage market?"

- Q3: "Is there a relationship between the mortgage lenders' financial strength and their advertising activities on the Czech mortgage market?"

- Q4: "Is there a relationship between the intensity of advertising and the number of new mortgage loans on the Czech mortgage market?" 


\section{Data and Methods}

The analysis is based on a dataset provided by the Nielsen Admosphere research agency, which monitors the mass media market in the Czech Republic. The database includes a complete set of ads on Czech TV, radio and in print since 2010. The sample contains information about 309,886 advertisements in the "Mortgages and Loans" category between 2010 and 2017, of which 131,758 are TV commercials, 170,113 are radio ads and 8,015 are advertisements in print. The advertising activities were analysed across all major media channels as the mass-media mix components are mutually supportive and complementary (Singh, 2011). All financial institutions $(\mathrm{n}=20)$ providing mortgage loans on the Czech market in the selected years were included in the analysis.

Each financial institution was represented by the following variables:

- age, calculated from the date of establishment of the mortgage lender in the Czech Republic;

- number of ads (TV, radio and print in total) for the institution in each year from 2010 to 2017 ;

- the cost of mass media communication in individual years;

- the total assets of the institution in individual years.

The statistical software R version 3.4.3 (R Core Team, 2017) was used for the analysis. Statistical methods are used to answer the research questions. Particular statistical methods are introduced in each of the following four subsections according to the research questions.

\subsection{Research Question 1}

For the purpose of this study, the mortgage lenders were divided into two groups: the younger mortgage lenders and the older ones (Table 1). The mortgage lenders who were established according to the business register after 1995 (Justice Ministry, 2017) were defined as younger mortgage lenders ( 8 financial institutions); the other 12 financial institutions were defined as older mortgage lenders.

Table 2 presents the basic descriptive statistics (mean, median, lower and upper quartiles) for the advertising activity (number and costs of advertisements) separately for older and younger mortgage lenders. The values of the statistics presented are higher for older mortgage lenders. Furthermore, there is a big difference between the means and medians for the same situations. This is due to the fact that the distributions of both variables for the "number of ads" and the "costs of ads" are considerably skewed.

In this study, we analyse the effect of age (represented by two groups) on advertising activity (number and costs of advertisements). As the study is based on longitudinal (panel) data, the age effect was evaluated by using the linear mixed model (Laird and Ware, 1982). To this end, each financial institution is considered as one panel member. Our model then includes the mortgage lender's age and year (of ad airing) as fixed effects with financial institution specific random intercept. Both "numbers of advertisements" and "costs of advertisements" outcome variables are entered into the model upon logarithmic transformation in the form $\log (1+$ value $)$ because of their considerable skewness. In particular, 
let $Y_{i, t}$ be the respective logarithmic outcome of financial institution $i(\mathrm{i}=1, \ldots, \mathrm{n})$ at year $t(\mathrm{t}=2010, \ldots, 2017)$, age $_{i}$ a dichotomous group allocation for financial institution $i\left(a g e_{i}=0\right.$ for younger mortgage lenders, $a g e_{i}=1$ for older mortgage lenders). Finally, let $d_{1}(t), \ldots, d_{7}(t)$ be dichotomous dummy variables representing years $2011, \ldots, 2017$. The following linear mixed model is used:

$$
Y_{i, t}=B_{i}+\beta_{0}+\beta_{1} d_{1}(t)+\ldots+\beta_{7} d_{7}(t)+\beta_{8} a g e_{i}+\varepsilon_{i, t},
$$

where $B_{i}(\mathrm{i}=1, \ldots, \mathrm{n})$ are i.i.d. normally distributed zero mean random intercepts with unknown variance $\sigma_{b}{ }^{2}$ and $\varepsilon_{i, t}$ are i.i.d. normally distributed zero mean error terms with unknown variance $\sigma_{\varepsilon}{ }^{2}$. In addition, this model implies a positive correlation between two outcomes obtained for one financial institution at two different time points and no particular trend over time is assumed. Finally, the model was estimated by the restricted maximum likelihood method (REML) using the R package lme4 (Bates et al., 2017).

Table 1 | List of all analysed institutions on the Czech mortgage market according to the date of establishment in the Czech Republic

\begin{tabular}{|l|r|l|c|}
\hline \multicolumn{2}{|c|}{ Older mortgage lenders } & \multicolumn{1}{c|}{$\begin{array}{c}\text { Younger mortgage lenders } \\
\text { Entablishment }\end{array}$} & $\begin{array}{c}\text { Date of } \\
\text { establishment }\end{array}$ \\
\hline Stavební spořitelna České spořitelny & $13 / 6 / 1994$ & Fio banka & $17 / 5 / 2010$ \\
\hline Waldviertler Sparkasse von 1842 AG & $21 / 4 / 1994$ & $\begin{array}{l}\text { Erste Bank (ERB } \\
\text { Bank) }\end{array}$ & $15 / 7 / 2008$ \\
\hline Modrá pyramida stavební spořitelna & $9 / 12 / 1993$ & mBank S.A. & $18 / 7 / 2007$ \\
\hline Raiffeisen stavební spořitelna & $4 / 9 / 1993$ & Oberbank AG & $1 / 11 / 2003$ \\
\hline Českomoravská stavební spořitelna & $27 / 8 / 1993$ & Wüstenrot & $23 / 12 / 2002$ \\
\hline Raiffeisenbank & $25 / 6 / 1993$ & Moneta Money Bank & $9 / 6 / 1998$ \\
\hline Equa bank & $6 / 1 / 1993$ & Sberbank CZ & $1 / 1 / 1997$ \\
\hline Komerční banka & $5 / 3 / 1992$ & UniCredit Bank & $1 / 1 / 1996$ \\
\hline Česká spořitelna & $30 / 12 / 1991$ & & \\
\hline Expobank CZ (LBBW Bank) & $23 / 1 / 1991$ & & \\
\hline Hypoteční banka & $10 / 1 / 1991$ & & \\
\hline ČSOB & $21 / 12 / 1964$ & & \\
\hline
\end{tabular}

Source: (Justice Ministry, 2017), authors' own research 
Table 2 | Descriptive statistics for the advertising activity per institution per year according to the companies' age group

\begin{tabular}{|l|c|c|c|c|c|c|}
\hline & \multicolumn{3}{|c|}{ Older mortgage lenders } & \multicolumn{3}{c|}{ Younger mortgage lenders } \\
\hline Variable & Mean & Median & Q1 - Q3 & Mean & Median & Q1 - Q3 \\
\hline Number of ads & 2650 & 84 & $1-2607$ & 866 & 1 & $0-450$ \\
\hline Costs of ads (million CZK) & 21.1 & 3.7 & $0.0-37.9$ & 8.3 & 0 & $0-10.5$ \\
\hline
\end{tabular}

Source: Authors' own research

\subsection{Research Question 2}

For the purpose of this study, the mortgage lenders are divided into two groups: the market challengers and the market leaders (Table 3). The mortgage lenders who owned more than a 20\% share of the Czech mortgage market in 2016 according to Skalková and Hovorka (2017) are defined as the market leaders. These are Hypoteční banka, Česká spořitelna, and Komerční banka. The others are defined as the market challengers.

Table 3 | List of all analysed institutions on the Czech mortgage market according to market position

\begin{tabular}{|l|l|}
\hline Market leaders & Market challengers \\
\hline Hypoteční banka & Českomoravská stavební spořitelna \\
\hline Česká spořitelna & Československá obchodní banka \\
\hline Komerční banka & Equa bank \\
\hline & Erste Bank (ERB Bank) \\
\hline & Expobank CZ (LBBW Bank) \\
\hline & Fio banka \\
\hline & Moneta Money Bank (GE Money Bank) \\
\hline & mBank \\
\hline & Modrá pyramida \\
\hline & Oberbank AG \\
\hline & Raiffeisen stavební spořitelna \\
\hline & Raiffeisenbank \\
\hline & Sberbank CZ \\
\hline & Stavební spořitelna České spořitelny \\
\hline & Unicredit Bank \\
\hline & Waldviertler Sparkasse von 1842 AG \\
\hline & Wüstenrot \\
\hline
\end{tabular}

Source: (Skalková and Hovorka, 2017), authors' own research 
Table 4 presents the basic descriptive statistics for the advertising activity (number and costs of advertisements) separately for market leaders and market challengers. The values indicate the higher advertising activity of market leaders. Again, there is a big difference between means and medians due to the considerable skewness distributions of the investigated variables.

As in the previous case (the section 1.1), the linear mixed model is used to investigate the effect of the market position on the advertising activity. The dichotomous variable "age $e_{i}$ " is replaced by the dichotomous variable "market ${ }_{\mathrm{i}}$ " (being equal to 0 if financial institution $i$ is a market challenger and equal to 1 if it is a market leader) in this case. Again, both the variables for the "number of advertisements" and "costs of advertisements" are entered into the model upon logarithmic transformation $\log (1+$ value $)$ because of their considerable skewness.

Table 4 | Descriptive statistics for the advertising activity per institution per year according to market position

\begin{tabular}{|l|c|c|c|c|c|c|}
\hline & \multicolumn{3}{|c|}{ Market leaders } & \multicolumn{3}{c|}{ Market challengers } \\
\hline Variable & Mean & Median & Q1 - Q3 & Mean & Median & Q1 - Q3 \\
\hline Number of ads & 7894 & 5600 & $1730-11657$ & 886 & 6 & $0-465$ \\
\hline $\begin{array}{l}\text { Costs of ads } \\
\text { (million CZK) }\end{array}$ & 49.0 & 39.6 & $35.8-57.9$ & 10.2 & 0.2 & $0.0-10.1$ \\
\hline
\end{tabular}

Source: Authors' own research

\subsection{Research Question 3}

Data provided by the Justice Ministry (2017) about institutions' total assets are used as a criterion of the mortgage lenders' financial strength. Twenty financial institutions provide mortgage loans on the Czech market. However, the reporting of total assets is only required (by law) for domestic financial institutions. Therefore, the branches of foreign financial institutions (for example, mBank S.A.) had to be omitted from the analysis of 19 institutions. Still, the research sample represents more than $90 \%$ of all mortgage loans provided in the selected years.

As data of the total assets were provided for particular years from 2010 to 2015 , the number of ads and expenditure for aired ads are analysed in this research question in the same period (2010-2015). Table 5 shows the descriptive statistics for the number of ads and both financial variables that have a skewed distribution.

Table 5 | Descriptive statistics for the investigated variables per institution per year

\begin{tabular}{|l|c|c|c|}
\hline Variable & Mean & Median & Q1 - Q3 \\
\hline Number of ads & 2050.1 & 48.5 & $0.0-2092.5$ \\
\hline Costs of ads (million CZK) & 16.9 & 2.7 & $0.0-33.5$ \\
\hline Total assets (million CZK) & 220 & 82 & $27-206$ \\
\hline
\end{tabular}

Source: Authors' own research 
For each company, the advertising activities (number or costs of advertisements) were analysed as a response and total assets analysed as a predictor. The "number of advertisements", "costs of advertisements", and "total assets" variables were entered into the model upon logarithmic transformation. Thus, $\log (1+$ values $)$ is used as a response in the linear mixed model, and $\log$ (assets) and year were used as fixed effects and random intercept for financial institutions. In particular, the dichotomous variable "age" in the linear mixed model (1) is replaced by the numeric variable "log $\left(\operatorname{assets}_{\mathrm{i}}\right)$ ".

\subsection{Research Question 4}

Since the mortgage sales data is only available for the entire market, this analysis focuses on the aggregate variables between 2010 and 2015. That means only six values for each investigated variable. To answer this research question, we analysed:

- the relationship between the aggregate number of advertisements and the number of new mortgage loans;

- the relationship between the total advertising expenditure and the contract principal amount (loan amount in CZK) of new mortgages per year.

In this study, the correlation between two time series is investigated. Using the correlation coefficient for the original values is not appropriate because of the possibility of spurious correlation. Therefore, the correlation is determined for residual (non-trend) values.

\section{Findings}

This results section is divided into four parts according to the four research questions.

\subsection{Analysis RQ1}

Figures 1 and 2 show the observed numbers or costs of advertisements after logarithmic transformation individually for each mortgage lender and as a whole for both age groups during 2010-2017. The group lines indicate higher advertising activity for older mortgage lenders (Figure 1). However, in 2013, the average advertising costs of the younger mortgage lenders were slightly higher (Figure 2). 
Figure 1 | Observed number of advertisements differentiating older (full line) and younger (dashed line) mortgage lenders

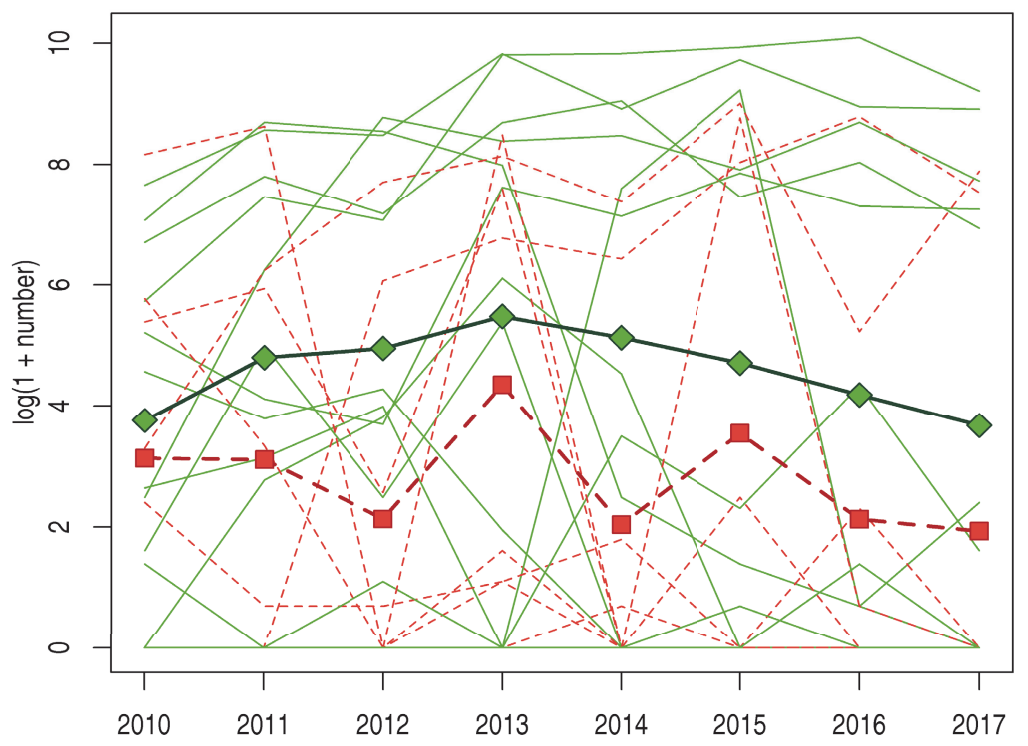

Source: Authors' own research

Figure 2 | Observed costs of advertisements differentiating older (full line) and younger (dashed line) mortgage lenders

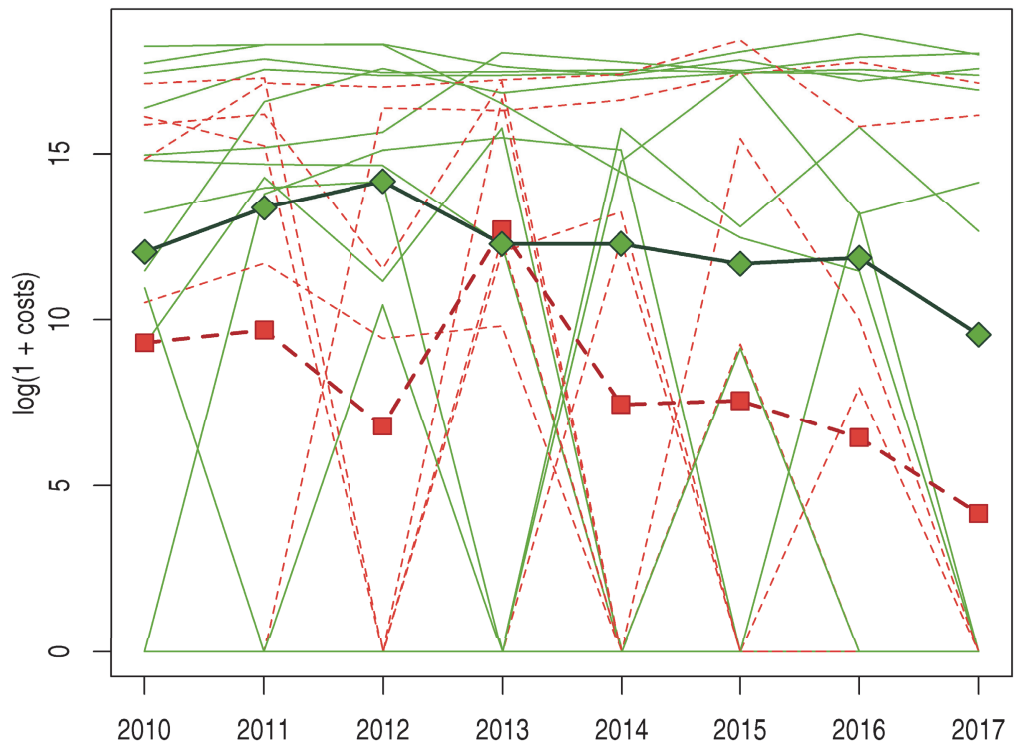

Source: Authors' own research 
Table 6 | Estimated ratios of expected numbers and costs of ads (adjusted for year and institution) between the older and younger mortgage lenders based on the linear mixed models

\begin{tabular}{|l|c|c|c|}
\hline Variable & Estimated Ratio & 95\% Conf. Int. & P-value \\
\hline Number of ads & 6.0 & $(0.5,78.0)$ & 0.171 \\
\hline Costs of ads & 62.7 & $(0.6,6255.8)$ & 0.078 \\
\hline
\end{tabular}

Source: Authors' own research

Table 6 provides estimated ratios of the expected numbers and costs of advertisements between the older and the younger mortgage lenders adjusted for the effect of a financial institution and temporal effects. The estimates were obtained as exponentiated values of the corresponding fixed effect $\left(\beta_{8}\right)$ from the mixed models given by (1). Additionally, related confidence intervals based on the maximum likelihood theory and p-values of the Wald test are provided. The results show no statistically significant difference in the advertising activity between older and younger mortgage lenders (at the 5\% significance level). Based on our results, the answer to research question Q1 is negative.

\subsection{Analysis RQ2}

Figures 3 and 4 show the observed numbers or costs of advertisements after logarithmic transformation individually for each mortgage lender and as a whole for both market position groups during 2010-2017. The group lines indicate higher advertising activity for market leaders (Figure 3). In particular, the average costs of advertising were relatively stable for the leaders and decreased for the challengers after 2013 (Figure 4).

Figure 3 | Observed number of advertisements differentiating market leaders (full line) and market challengers (dashed line)

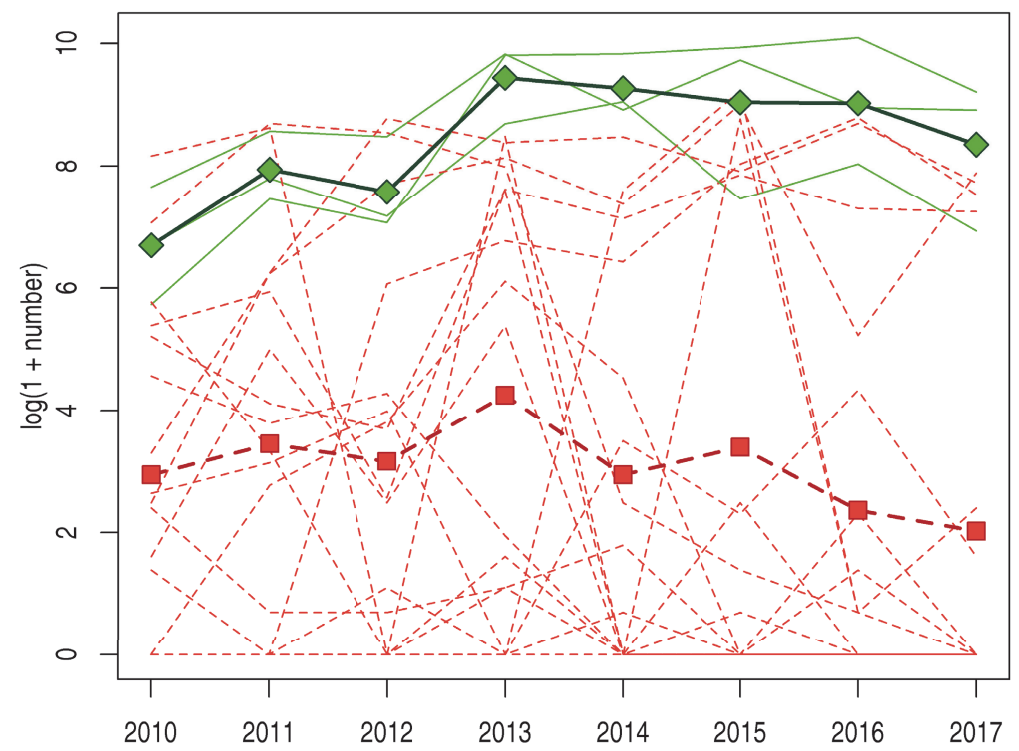

Source: Authors' own research 


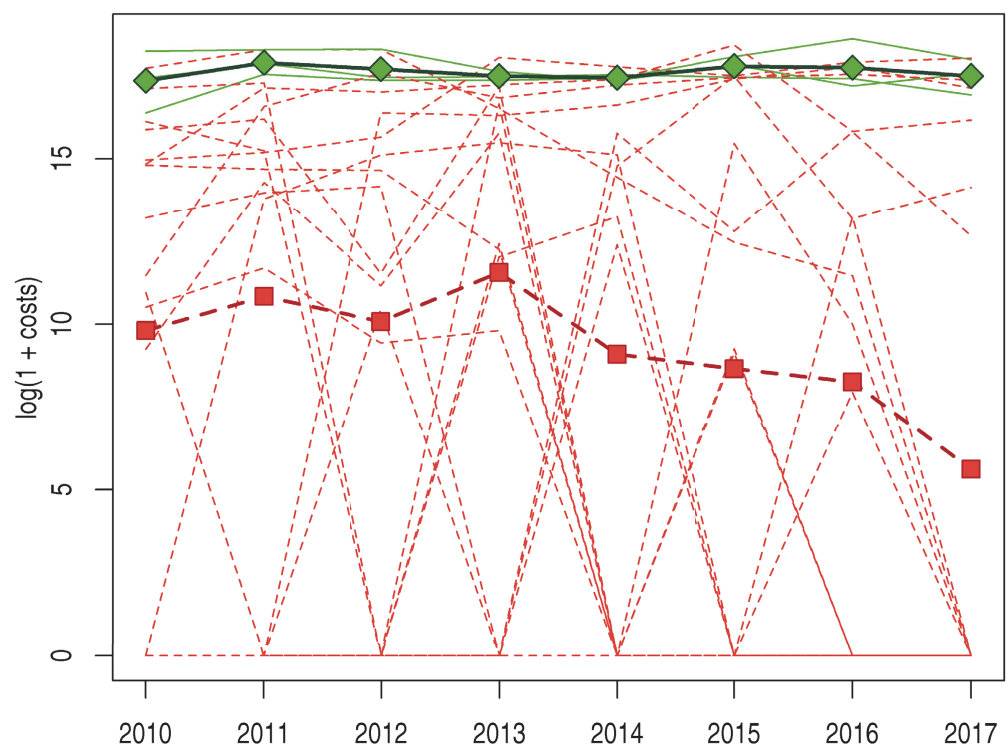

Source: Authors' own research

Table 7 | Estimated ratios of expected numbers and costs of ads (adjusted for year and institution) between the market leaders and market challengers based on the linear mixed models

\begin{tabular}{|l|c|c|c|}
\hline Variable & Estimated Ratio & 95\% Conf. Int. & P-value \\
\hline Number of ads & 211.2 & $(13.5,3302.0)$ & $<0.001$ \\
\hline Costs of ads & 4259.1 & $(15.1,1203836.0)$ & 0.004 \\
\hline
\end{tabular}

Source: Authors' own research

Table 7 shows the estimated ratios of expected advertising activity (measured by numbers of ads and by costs of ads) between the market leaders and market challengers adjusted for the effect of a financial institution and temporal effects. Contrary to the previous case, there is a statistically significant difference in the advertising activity between market leaders and market challengers in both cases. This provides a positive answer to Q2: the market leaders have a higher advertising activity. First, market leaders have an average number of ads 211 times higher than market challengers. Second, market leaders spend $4259 \times$ more money on average than market challengers. Both results are adjusted for the year and the financial institution. 


\subsection{Analysis RQ3}

Using the linear mixed model, we obtained the estimated effect of $\log$ (assets). The results are summarised in Table 8. Namely, unity increase of the expected $\log (1+$ numbers $)$ related to the unity increase of $\log$ (assets) is 1.35 , given the financial institution and year. The unity increase of the expected $\log (1+$ costs $)$ related to the unity increase of the $\log ($ assets $)$ is 2.48 , given the financial institution and the year. The corresponding $\mathrm{p}$-values are $\mathrm{p}<0.001$ in both cases. Therefore, we can conclude that there is a statistically significant relationship between the mortgage lenders' financial strength and their advertising activities on the Czech mortgage market while the trend is increasing.

Table 8 | Estimated effects of the log(total assets) (adjusted for year and institution) in the linear mixed model for the $\log ($ number of ads +1$)$, or the $\log (\operatorname{costs}$ of ads +1$)$, respectively

\begin{tabular}{|l|c|c|c|}
\hline Response & Estimate & 95\% Conf. Int. & P-value \\
\hline $\log ($ Number of ads + 1) & 1.35 & $(0.79,1.92)$ & $<0.001$ \\
\hline $\log ($ Costs of ads +1$)$ & 2.48 & $(1.39,3.56)$ & $<0.001$ \\
\hline
\end{tabular}

Source: Authors' own research

\subsection{Analysis RQ4}

Figure 5 shows scatterplots with estimated correlations and corresponding 95\% confidence intervals based on the Fisher Z-transformation along with the related p-values. Note that the analysis is based on only six observations (years 201-2015) of each quantity and hence, the length of the confidence intervals is rather high. The investigated correlations for original time series values are 0.97 for the number of ads versus the number of mortgages, or 0.56 for the cost of ads versus mortgage loans. The investigated correlations for residuals (while assuming a linear trend for the original time series) are in both cases quite high (0.74 and 0.89$)$ with a positive indication. If we focus on statistically significant results, there is always only one pair (original, detrended values) that is significant. We conclude a clear trend towards a positive relationship between the intensity of advertising and the number of new mortgage loans on the Czech mortgage market. Nevertheless, data for additional years would be needed to claim statistically significant correlations in all cases. To summarise, the results partially provide a positive answer to research question Q4. 
$r=0.97(0.71,1.00), p=0.002$

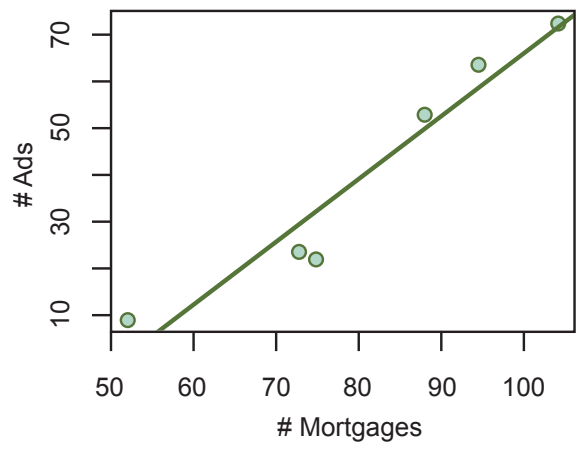

$r=0.74(-0.18,0.97), p=0.094$

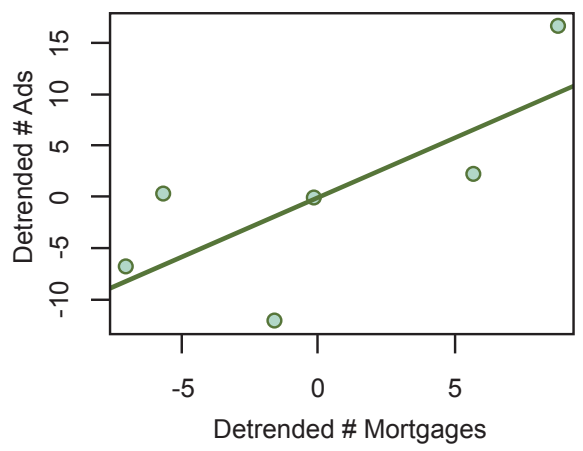

$r=0.56(-0.46,0.94), p=0.249$

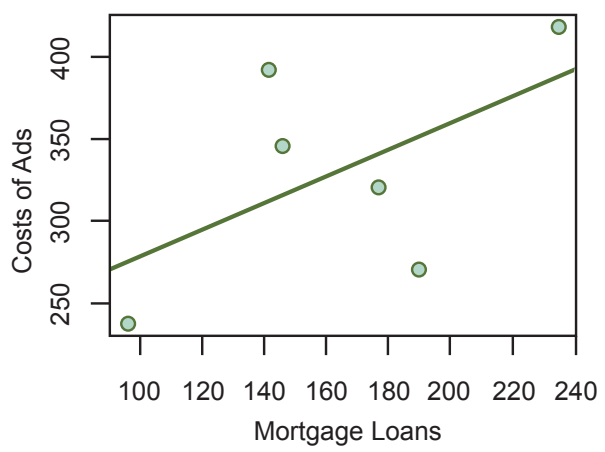

$r=0.89(0.27,0.99), p=0.019$

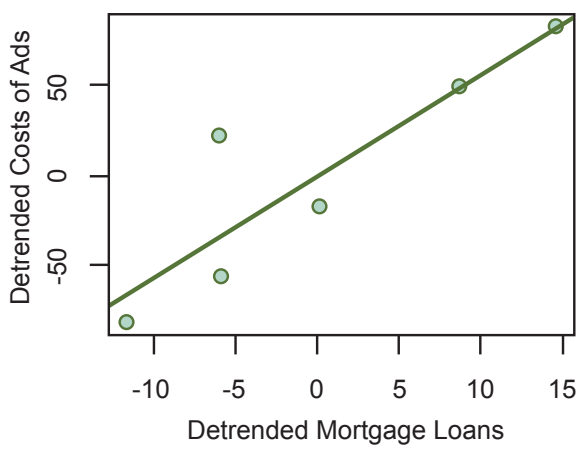

Source: Authors' own research

\section{Discussion}

The analysis of Q1 revealed no statistically significant difference in the volume of advertisements between the older and the younger mortgage lenders (at the 5\% significance level). This may be related to the fact that not all financial institutions considered to be older mortgage lenders can be perceived as market leaders (compare Table 1 and Table 3). Moreover, the analysed period (2010-2017) was characterised as a rebirth of the market after the housing bubble burst in 2008 (Mantell, 2009). The Czech mortgage market did not experience such a devastating drop as the US market although the number of new mortgage loans dropped by almost 50\% in 2007-2009 (Ministry Of Regional Development CZ, 2015). Through an intensive marketing campaign, the market leaders attempted to revive the demand for their products. Therefore, the mortgage lenders focused on reviving the demand for their products through such intensive performance marketing campaigns, rather than on brand marketing. 
Contrary to the previous, the analysis of Q2 suggested a statistically significant difference in the volume of advertisements between market leaders and market challengers in both cases. Larger companies usually utilise more diversified media portfolios, i.e. using multiple channels of media communication. Medium and small companies stay more focused using only one or just a few selected media types, thus missing out on the ability to achieve synergies and multiplication effects between the channels. In the analysed period, the market challengers did not run more intensive marketing campaigns to obtain the share of market leaders. Moreover, the larger volume of advertising did not necessarily mean higher advertising expenditures. Larger subjects have a better negotiating position as buying large volumes of advertising space usually leads to better pricing schemes. The results also suggest that the mass media activity of companies on the mortgage market relates more to their financial strength than to their age. Such findings resonate with previously undertaken studies, i.e. Wright and Watkins (2010).

The estimated effect of financial strength and companies' advertising activities was analysed in Analysis Q3. Using the linear mixed model, the results suggest that the unity increase of the expected $\log (1+$ costs $)$ related to the unity increase of $\log ($ assets $)$ is 2.48 , given the financial institution and the year. We can conclude that there is a statistically significant relationship between the mortgage lenders' financial strength and their advertising activities on the Czech mortgage market with an increasing trend. Such a conclusion is in line with the assumption that larger financial institutions (with greater financial strength) have more resources available to support their activities through marketing communication. However, this result does not truly reflect the relationship between the financial strength of the institution and the volume of advertisements as a larger subject can negotiate much better pricing schemes, as they buy larger volumes of advertising space.

The final analysis addressed the relationship between the intensity of advertising and the number of new mortgage loans. Since the mortgage data was only available for the entire market, this analysis focused on the aggregate variables between the analysed years. The results revealed a positive relationship between the intensity of advertising and the number of new mortgage loans on the Czech mortgage market. However, such findings must be considered with caution, since the length of the time series was small and correlations are not statistically significant for all considered situations. Moreover, correlation does not imply causation. The increasing intensity (either the volume of advertisements or the advertising expenditures in the analysed years) of marketing communication and the increasing number of new mortgage loans might be related to the market resurrection after the global crisis in 2008-2010. Thus, the market leaders' strategies probably focus more on expanding the total demand than protecting their market share.

\section{Conclusion}

The motivation for this study was the lack of studies and literature on mass media communication in the banking industry. From the theoretical perspective, the study confirms the different advertising patterns of the market leaders and the challengers on a highly commoditised mortgage market. Contrary to the initial expectation, the market leaders did not utilise defensive strategies to protect their market share but employed more offensive strategies to increase the size of the market. The challengers had no resources to implement a massive and offensive communication strategy to challenge the market 
leaders. Such a conclusion contributes to the debate on communication strategies for distinct types of companies according to their position on the market and their market share. The study provides useful information for marketing practitioners and managers in the Czech banking industry about the advertising activities and behavioural patterns of their competitors on the mass media market. The results can also serve as a methodological basis for studies in other countries, enabling a cross-national comparison in order to provide a deeper insight into the analysed issue.

Even though the analysis offers some informative conclusions, it should be accepted with caution. Only one market was examined in this case and thus the conclusions cannot be generalised. The analysis also does not consider the delay in reactions between variables, i.e. the increase in mass media communication activities does not affect purchases immediately. This presents significant opportunities for further research.

\section{References}

Accenture, (2015). Mortgage Lending Shaped by the Customer, North America Consumer Digital Banking Survey for Lenders. [online] Available at: www.accenture.com/t20150626T121133__w__/us-en/_acnmedia/Accenture/ConversionAssets/DotCom/Documents/Global/PDF/Dualpub_9/Accenture-Consumer-MortgageLenders.pdf [Accessed 13 Jan. 2017].

Allen, J., Clark, R. and Houde, J. F. (2014). The Effect of Mergers in Search Markets: Evidence from the Canadian Mortgage Industry. The American Economic Review, 104(10), pp. 3365-3396, https://doi.org/10.1257/aer.104.10.3365

Bates, D. et al. (2017). Ime4: Linear Mixed-Effects Models using 'Eigen' and S4. [online] R package, version 1. Available at: http://cran.r-project.org/package=Ime4 [Accessed 31 Jan. 2018].

Borden, N. H. (1942). The Economic Effects of Advertising. Chicago: Richard D. Irwin.

Cavaliere, G. and Tassinari, G. (2001). Advertising Effect on Primary Demand: A Cointegration Approach. International Journal of Advertising, 20(3), pp. 319-339, https://doi.org/10.1080/0 2650487.2001.11104896

Cowling, K., Cable, J., Kelly, M. and Mcguinness, T. (1975). Advertising and Economic Behaviour. London: The Macmillan Press.

CNB (Czech National Bank), (2015). Zpráva o inflaci IV/2015 [Inflation Report IV/2015]. [online] Praha: Czech National Bank (in Czech). Available at: www.cnb.cz/miranda2/export/sites/ www.cnb.cz/cs/menova_politika/zpravy_o_inflaci/2015/2015_IV/download/zoi_IV_2015. pdf [Accessed 26 Nov. 2016].

Geskey, R. D. (2015). Media Planning and Buying in the 21st Century, 3rd ed. B.m.: Create Space Independent Publishing Platform.

Grabowski, H. G. (1977). The Effects of Advertising on Intraindusty Shifts in Demand. In: Explorations in Economic Research, 4(5), 1st ed. NBER, pp. 81-107.

Honka, E., Hortaçsu, A. and Vitorino, M. A. (2017). Advertising, Consumer Awareness, and Choice: Evidence from the US Banking Industry. The RAND Journal of Economics, 48(3), pp. 611-646, https://doi.org/10.1111/1756-2171.12188

Kotler, P. and Armstrong, G. (2012). Principles of Marketing, 14th ed. London: Pearson.

Kotler, P. and Keller, K. L. (2016). Marketing Management. Boston: Pearson.

Kwoka, Jr. J. E. (1993). The Sales and Competitive Effects of Styling and Advertising Practices in the US Auto Industry. The Review of Economics and Statistics, pp. 649-656, https://doi.org/10.2307/2110018 
Laird, N. M. and Ware, J. H. (1982). Random-effects Models for Longitudinal Data. Biometrics, 38(4), pp. 963-974, https://doi.org/10.2307/2529876

Mantell, R. (2009). Home Prices Off Record 18\% in Past Year, Case-Shiller says. [online] MarketWatch. Available at: www.marketwatch.com/story/home-prices-off-record-18-inpast-year-case-shiller-says [Accessed 15 Jun. 2017].

Ministry of Regional Development CZ, (2015). Hypoteční úvěry (2002-2015) [Mortgage Loans (2000-2015)]. [online] Ministerstvo pro místní rozvoj ČR. Available at: www.mmr.cz/getmedia/2f7455ca-4160-4d51-9bf2-24633cec4220/Hypotecni-uvery-zaroky-2002-az-4Q-2015,-k-31-12-15.pdf?ext=.pdf [Accessed 1 Jun. 2017]

Justice Ministry, (2017). Obchodní rejstřík [Business Register]. [online] Ministerstvo spravedlnosti [Accessed 1 Dec. 2017]. Available at: portal.justice.cz/Justice2/Uvod/uvod.aspx

Mullineaux, D. J. (2011). How Much Does Marketing Matter to Bank Performance? [online] Mullineaux Management. Available at: www.mullineaux.com/does_marketing_matter.pdf [Accessed 13 Jan. 2017].

Nelson, J. P. (2005). Beer Advertising and Marketing Update: Structure, Conduct, and Social Costs. Review of Industrial Organization, 26(3), pp. 269-306, https://doi.org/10.1007/s11151-004-8113-x

Nielsen Admosphere, (2015). TZ Hypotéky: stále důležité téma pro velkou část českých domácností i zadavatele reklamy [PR Mortgage: Still an Important Topic for Most Czech Households and Advertisers]. [online] Nielsen Admosphere (in Czech). Available at: www.nielsen-admosphere.cz/press/hypoteky-stale-dulezite-tema-pro-velkou-castceskych-domacnosti-i-zadavatele-reklamy/ [Accessed 23 Nov. 2016].

Patterson, J. (1977). Structure and Strategy in the Gasoline Industry. Strategy + Structure = Performance, pp. 81-99.

Rosen, C. B. (1989). The Effectiveness of Advertising on Sales in the Banking Industry. MBA report, University of the Witwatersand, Johannesburg, RSA.

R Core Team, (2017). R: A Language and Environment for Statistical Computing. [online] R Foundation for Statistical Computing. Available at: https://www.r-project.org/ [Accessed 31 Jan. 2018].

Singh, S. (2011). TV Ads' New Digital Role. [online] Harvard Business Review, 89. Available at: https://hbr.org/2011/11/the-new-role-of-television-adv [Accessed 31 Jan. 2018].

Skalková, O. and Hovorka, J. (2017). Jednička na trhu hypoték zvyšuje náskok před konkurencí. Známe nová ćísla [The first leader in the mortgage market increases the margin over the competition. Know the new numbers]. [online] Economia, a.s. Available at: zpravy.aktualne.cz/ekonomika/jednicka-na-trhu-hypotek-zvysuje-naskok-predkonkurenci-znam/ [Accessed 20 Mar. 2017].

Steiner, R. (1978). Learning from the Past - Brand Advertising and the Great Bicycle Craze of the 1890s. Paper presented at the Annual Conference of the American Academy of Advertising: Advances in Advertising Research and Marketing.

Taylor, L. D. and Weiserbs, D. (1972). Advertising and the Aggregate Consumption Function. American Economic Review, 62(4), pp. 642-655.

Wright, M. and Watkins, T. (2010). Marketing Financial Services, 2nd ed. Oxford: ButterworthHeinemann.

Zahrádka, P. and Sedláková, R. (2012). Theory and Research on Consumer Culture in the Czech Republic before and after 1989. In: P. Zahrádka and R. Sedláková, eds., New Perspectives on Consumer Culture Theory and Research, 1st ed. Newcastle upon Tyne: Cambridge Scholars Publishing, pp. 12-38. 